13. Zibert, G. K., Sedykh, A. D., Kashitskiy, Yu. A., Mikhailov, N. V., Demin, V. M. (2001) Podgotovka i pererabotka uglevodorodnykh gazov i kondensata. Tekhnologii i oborudovaniye [Preparation and Processing of Hydrocarbon Gases andCondensate. Technology and Equipment: Handbook]. Moskow: OAO Nedra-Biznestsentr, 316.

14. Sedak, V. S. (1999). Kompyuternye tekhnologii v razrabotke i ekspluatatsii regionalnykh system gazosnabzheniya na primere OAO GGO "Kharkovgas" [Computer technology in the development and operation of regional gas supply systems by the example of MGO "Kharkovgas"]. Kharkov, 182.

15. Nefedov, L. I., Petrenko, Yu. A., Shevchenko, M. V., Binkovskaya, A. B. (2012) Metodologicheskiye osnovy sinteza ofisov po upravleniyu programmami i proektami [Methodological bases synthesis of offices for program and project management]. Kharkov: KHNADU, 296.

16. Petrov, E. G., Pisklakova, B. P., Beskorovaynyy, V. V. (1992). Territorialno raspredelennye sistemy obsluzhivaniya [Territorially distributed service system]. Kyiv: Tekhnika, 208.

Нефедов Леонид Иванович, доктор технических наук, профессор, кафедра автоматизации и компьютерно-интегрированных технологий, Харьковский национальный автомобильно-дорожный університет, Петровского, 25, г. Харьков, Украина, 61002

E-mail: nefedovli@rambler.ru

Шевченко Мария Валерьевна, кандидат технических наук, доцент, кафедра автоматизации и компьютерно-интегрированных технологий, Харьковский национальный автомобильно-дорожный университет, Петровского, 25, г. Харьков, Украина, 61002

E-mail: BECHA_MV@mail.ru

Кудырко Ольга Николаевна, аспирант, зав. лаб., кафедра автоматизации и компьютерноинтегрированных технологий, Харьковский национальный автомобильно-дорожный университет, Петровского, 25, г. Харьков, Украина, 61002

E-mail: olya_kud@mail.ru

УДК 662.767.2

\title{
ВИРОБНИЦТВО БІОГАЗУ 3 ВІДХОДІВ ТВАРИННИЦТВА ЯК ЕЛЕМЕНТ ЕНЕРГОРЕСУРСОЗБЕРЕЖЕННЯ
}

\author{
() І. С. Козій, С. С. Мелейчук, В. В. Волохін
}

У статті розглядається можливість отримання біогазу з відходів тваринницького комплексу. Використання даного енергоносія є досить актуальним для більшості господарств і дозволяє вирішити ряд питань екологічного, енергетичного та економічного напряму. В статті проведено дослідження складу та теплотворної здатності отриманого біогазу, а також наведено пропозиції щчодо подальщого застосування.

Ключові слова: біогаз, енергозбереження, тваринництво, забруднення, біореактор, біодобрива, метан.

This paper deals with the possibility of obtaining biogas from livestock waste sector. The use of this energy source is still relevant for most households and can solve a number of issues of environmental, energy and economic direction. The paper studied the composition and calorific value of biogas obtained, and proposals for future reference are provided.

Keywords: biogas, energy, farming, pollution, bioreactor, biofertilizers, methane.

\section{1. Вступ}

Вирішення глобальних проблем енергетичної безпеки в наші дні визначає не тільки темпи соціально-економічного розвитку, але й виживання людства в майбутньому. Сьогодні в усьому світі потребують вирішення дві взаємозалежні проблеми: економія паливно-енергетичних ресурсів i зменшення забруднення навколишнього середовища. В умовах виснаження запасів органічного палива й різкого підвищення витрат на освоєння нових родовищ стає усе більш нераціональним спалювання вугілля й нафтопродуктів у мільйонах малопотужних котельних і індивідуальних топкових агрегатах, що викликає велику кількість шкідливих викидів в атмосферу й істотне погіршення екологічної обстановки в містах і світі.
Використання традиційних паливноенергетичних ресурсів веде до забруднення навколишнього середовища. Забруднення атмосфери при використанні не поновлюваних джерел енергії також веде до загального потепління, танення полярної криги і підвищення рівня світового океану протягом наступних століть. Ефективне і правильне використання енергоресурсів - ключ до успішного вирішення екологічної проблеми.

\section{2. Постановка проблеми}

Основною енергетичною задачею на даний момент $\epsilon$ переведення сільськогосподарських підприємств на поновлювані палива місцевого виробництва. Перспективним для сільськогосподарського сектора економіки 
вважається виробництво і використання біогазу, основною складовою якого $\epsilon$ метан. Відповідно головним завданням роботи $\epsilon$ дослідження можливості отримання біогазу 3 відходів тваринництва, на прикладі одного 3 фермерських господарств, обговорення технологічної схеми виробництва та оцінки отриманого газоподібного енергоносія.

\section{3. Літературний огляд}

Структура споживання енергетичних ресурсів в Україні така, що має місце недолік природного газу й нафтопродуктів, (основний обсяг поставляється ізза кордону) і надлишок електричної енергії, частина якої йде на експорт. При цьому структура української економіки (раніше - складової частини надлишку енергоресурсів економіки СРСР) така, що недолік природного газу й нафтопродуктів робить її залежною від країн - постачальників цих ресурсів.

Динаміка розвитку світової галузі «зеленої енергетики» свідчить про економічну доцільність «зелених» інвестицій. Для України «зелений» вектор розвитку економіки є актуальним через необхідність заміщення природного газу й кам'яного вугілля альтернативними, такими що мають значний потенціал, енергоресурсами. Одним із таких напрямів $\epsilon$ біотехнологія, а саме виробництво біогазу 3 органічних відходів [1].

Біомаса, в тому числі і відходи тваринництва, дає сьому частину світового обсягу палива, а за кількістю отриманої енергії займає поряд із природним газом третє місце. 3 біомаси одержують у 4 рази більше енергії, ніж дає ядерна енергетика [2]. Все більшого поширення нині набувають технології використання біомаси шляхом іiі конверсії на більш ефективніші енергоносії, зокрема на біогаз, біодизельне моторне паливо, піролізний та генераторний газ, спиртові моторні палива. Серед енергоносіїв, отриманих із біомаси, за комплексною оцінкою, особливо за врахування нинішньої кон'юнктури цін на паливно-енергетичні ресурси, найбільш перспективним для України є біогаз [3]. Біогаз отриманий 3 органічного матеріалу буде відрізнятися дещо меншою теплотворністю, проте становить значну конкуренцію енергоносіям за рахунок низької вартості або взагалі безкоштовної вихідної сировини.

3 лютого 2011 року Україна стала членом Свропейського Енергетичного Співтовариства, метою діяльності якого є лібералізація енергетичних ринків та запровадження законодавчих норм Свропейського Союзу у галузях електроенергетики, газу, охорони навколишнього середовища i поновлюваних джерел енергії. Україна як член Європейського Енергетичного Співтовариства повинна виконати вимоги щодо недискримінаційного доступу біогазу до газової системи 3 урахуванням відповідних норм та стандартів до якості газу [4].

У липні 2010 року був прийнятий Закон України «Про засади функціонування ринку природного газу», відповідно до ст. 7 якого всі суб'єкти ринку природного газу мають рівні права доступу до Єдиної газотранспортної системи України [5]. Закон не містить жодних положень, які б стосувалися доступу до газотранспортної системи виробників біогазу, що позбавляє цих суб'єктів можливостей бути повноцінними суб'єктами ринку природного газу. Біогаз визначено в ст. 1 Закону України «Про альтернативні види палива» як газ, отриманий 3 біомаси, що використовується як паливо. В Законі також містяться загальні положення щодо організаційно-економічних заходів щодо стимулювання виробництва (видобутку) та споживання альтернативних видів палива [5]. Розроблення чітких цілей і механізмів стимулювання використання біогазових технологій сприяло би прискоренню розвитку біоенергетики та переходу до екологічно-зрівноваженого розвитку в Україні.

Актуальність даного матеріалу зумовлена тим, що особливо гостро останні роки стоїть проблема утилізації значної кількості відходів сільського господарства (особливо тваринництва), що завдають значної шкоди довкіллю. На базі біогазових установок можна організовувати цілий комплекс 3 безвідходної переробки відходів. Впровадження безвідходних технологій на базі біотехнології в тваринництві має багато позитивних сторін: усувається проблема знешкодження відходів тваринництва та харчової промисловості, підвищується частка поновлюваної енергетики в загальній енергетичній картині України, є ресурс підвищення та відновлення родючості грунтів.

\section{4. Виробництво біогазу 3 відходів тваринництва}

Для оцінки можливості отримання біогазу було створено експериментальну біогазову установку на базі фермерського господарства в Шосткинському районі Сумської області. Основний напрямок діяльності господарства - зерново-м'ясний і має статус племінного заводу 3 розведенням спеціалізованої м'ясної худоби української м'ясної породи. Підприємство працює прибутково. Рентабельність становить щорічно - 15-20\%.

За підрахунками, дана кількість ВРХ, що знаходиться на агрофірмі, здатна щодня утворювати близько 3,3 т гною (без врахування води на змив).

Отримана кількість гною щодня накопичується на території господарства і лише в незначній мірі використовується у вигляді перегною. Понад $50 \%$ утвореного гною розбирається працівниками господарства та жителями ближнього села.

Свіжий гній тваринницьких ферм і рідкі складові гною разом із стічними водами $\epsilon$ забруднювачами навколишнього середовища. Підвищена сприйнятливість сільськогосподарських культур до свіжого гною приводить до забруднення грунтових вод i повітряного басейну, створює сприятливе середовище для зараженості грунту шкідливими мікроорганізмами. У гної тварин життєдіяльність хвороботворних бактерій і яєць гельмінтів не припиняється, насіння смітних трав, що міститься в ньому, зберігає свої властивості $[6,7]$. 
Для усунення цих негативних явищ необхідна спеціальна технологія обробки гною, що дозволяє підвищити концентрацію живильних речовин i одночасно усунути неприємні запахи, подавити патогенні мікроорганізми, понизити зміст канцерогенних речовин. Перспективним, екологічно безпечним i економічно вигідним напрямом рішення цієї проблеми $є$ анаеробна переробка гною і відходів в біогазових установках 3 отриманням біогазу [8].

Особливістю цієї біогазової установки є наявність спеціальної ємності для підготовки сировини, звідки вона подається за допомогою вакуумного насоса в бункер завантаження, а потім за допомогою стиснутого біогазу - в реактор установки який наведено на рис. 1. і виконано 3 порожнього поліетиленового резервуару. Для роботи системи обігріву використовується частина вироблюваного біогазу. Установка забезпечена автоматичним відбором біогазу і газгольдером для його зберігання. Наявність системи обігріву дозволяє експлуатувати біогазові установку у всіх режимах бродіння.

Сировина з бункера завантаження надходить у метантенк, де відбувається процес бродіння, у результаті чого утворюється біогаз, що надходить через конденсатовловлювач у газгольдер. Частина біогазу направляється на спалювання і нагрівання теплоносія в тепловій рубашці для підтримки необхідної температури в метантенку [9]. Перемішування біомаси відбувається за допомогою газової мішалки, що використовує стиснений газ. Відпрацьована сировина з метантенка надходить у сховище біодобрив.

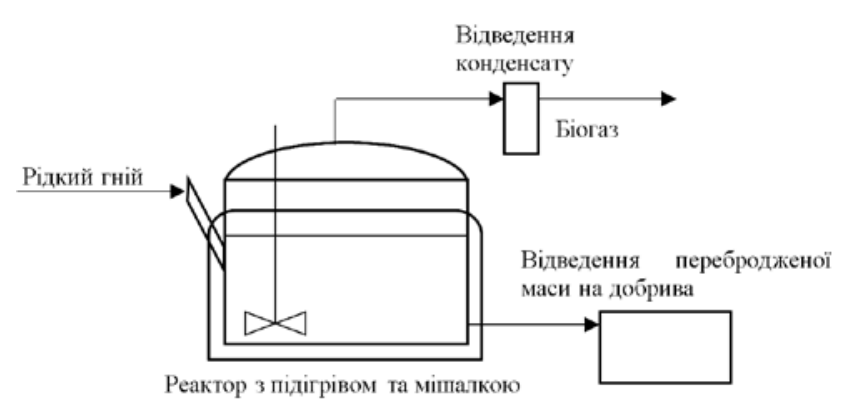

Рис. 1. Схема експериментальної біогазової установки на агрофірмі

Схожі конструкції даної біогазової установки використовуються в Вінницькій області для переробки силосу та відходів соняшника.

\section{5. Апробація результатів дослідження}

Період метанового бродіння в реакторі складає 30 діб. Після чого було відібрано проби газу у спеціальні скляні ємкості, що герметизувались парафіном і в яких газ знаходився під тиском 0,2 атм. На аналіз проби відправлялись до лабораторії хімічного аналізу газу ВАТ «Сумигаз» НАК «Нафтогаз України».

Аналіз проб газу проводився на газовому хроматографі Кристал-2000М (свідоцтво про повірку №797 від 15.05.14), 3 використанням повірочної газової суміші компонентів природнього газу (паспорт №252П-44/14 від 01.04.14). Методика аналізу ДСТУ ISO 6974-1:2007, ДСТУ ISO 69744:2007.

Результати аналізу наведено в табл. 1.

Таблиця 1

Результати хроматографічного аналізу проб біогазу, компонентний хімічний склад (\% об.)

\begin{tabular}{|c|c|c|c|c|c|c|c|}
\hline $\begin{array}{l}\text { № } \\
\text { 3/ח }\end{array}$ & Назва компонента & Проба 1 & Проба 2 & Проба 3 & Проба 4 & Проба 5 & $\begin{array}{l}\text { Середнє } \\
\text { значення }\end{array}$ \\
\hline 1 & Кисень & 2,31 & 2,41 & 2,56 & 2,44 & 2,39 & 2,42 \\
\hline 2 & Азот & 21,1 & 20,53 & 22,08 & 21,6 & 21,48 & 21,36 \\
\hline 3 & Двоокис вуглецю & 10,74 & 11,94 & 10,87 & 10,74 & 10,96 & 11,05 \\
\hline 4 & Метан & 65,85 & 65,13 & 64,49 & 65,22 & 65,17 & 65,17 \\
\hline \multicolumn{2}{|c|}{$\begin{array}{l}\text { Теплота } \\
\text { ккал/м }\end{array}$} & 5255 & 5197 & 5147 & 5209 & 5201 & 5202 \\
\hline \multicolumn{2}{|c|}{ Щільність газу, кг/м ${ }^{3}$} & 0,914 & 0,926 & 0,922 & 0,924 & 0,919 & 0,921 \\
\hline
\end{tabular}

Як бачимо з таблиці нижня теплота згоряння отриманого газу суттєво відрізняється від показників природного газу (7100 ккал/м $\left.{ }^{3}\right)$ проте існуючі технології розподілу газових сумішей (метод коротко циклової безнагрівної адсорбції $(\mathrm{PSM}))$ можуть підвищити цей показник $[10,11]$. Проте навіть спалювання такої газової суміші цілком задовольняє господарчі потреби невеликих господарств. Також не варто забувати про залишковий продукт метанового бродіння - рідкі біодобрива, які можна використовувати безпосередньо на земельних угіддях господарств або навіть фасувати на продаж.

\section{6. Висновки}

Наявні у кожному господарстві великі обсяги органічних відходів доцільно утилізувати 3 максимальним сумарним ефектом вирішення комплексних задач: енергетичної, екологічної, постачання власного господарства добривами, запобігання зараженню грунтових вод тощо. Так, зокрема, на прикладі агрофірми в експериментальній установці було отримано біогаз, що може бути використаний для господарських потреб (при горінні не кіптить і не дає запаху), а також рідкі добрива, які можуть бути внесені безпосередньо на поля господарства. Збільшення габаритів подібної 
біогазової установки в перспективі може повністю забезпечити енергетичні витрати господарства.

\section{Література}

1. Energy for the future: Renewable Sources of energy. White paper for a community strategy and action plan [Text] / Bruxelles, 1997. - 53 p.

2. Yadvika. Enhancement of biogas production from solid substrates using different techniques [Text] / Yadvika, Santosh \& other // Bioresource Technology. 2004. - Vol. 95(1). - P. 1-10. DOI:10.1016/j.biortech.2004.02.010.

3. Бурлакова, I. М. Еколого-економічний потенціал використання біогазових технологій у сільському господарстві [Текст] / І. М. Бурлакова, О. В. Кубатко, Є. I. Зябіна // Вісник СумДУ. Серія Економіка. - 2013. - № 4. - С. 19-25.

4. Шульц, Р. Виробництво і використання біогазу в Україні [Текст] / Р. Шульц. - К. : Бізнесцентр «Свразія», 2012. - 40 с.

5. Закон України «Про засади функціонування ринку природного газу» від 8 липня 2010 р. № 2467VI [Текст] / Відомості Верховної Ради України (BBP), 2010. - № 48. - C. 566.

6. Amona, T. Biogas production from maize and dairy cattle manure [Text] / T. Amona, B. Amona \& other // Agriculture, Ecosystems \& Environment. 2007. - Vol. 118 (1-4). - P. 173-182. DOI: 10.1016/j.agee.2006.05.007.

7. Cuellar, A. D. Cow power: the energy and emissions benefits of converting manure to biogas [Text] / A. D. Cuellar, M. E. Webber // Environ. Res. Lett. 3. - 2008. - 034002. - 8 p.

8. The Official Information Portal on Anaerobic Digestion [Electronic resource] / Available at : www.biogas-info.co.uk. - Title in screen.

9. Alvareza, R. Biogas production from llama and cow manure at high altitude [Text] / R. Alvareza, S. Villca, G. Lidén // Biomass and Bioenergy. - 2006. Vol. 30 (1). - P. 66-75. DOI: 10.1016/ j.biombioe.2005.10.001.

10. Biogas upgrading and utilization: Energy from biological conversion of organics waste [Text] / N. Y.: IEA Bioenergy, 2007. - Task 24. - 24 p.
11. Holm-Nielsena, J. B. The future of anaerobic digestion and biogas utilization [Text] / J. B. HolmNielsena, T. Al Seadi, P. Oleskowicz-Popiel // Bioresource Technology. - 2009. - Vol. 100 (22). P. 5478-5484. DOI: 10.1016/j.biortech.2008.12.046.

\section{References}

1. Energy for the future: Renewable Sources of energy. White paper for a community strategy and action plan (1997). Bruxelles, 53.

2. Yadvika, Santosh (2004). Enhancement of biogas production from solid substrates using different techniques. Bioresource Technology, 95 (1), 1-10. DOI: 10.1016/j.biortech.2004.02.010.

3. Burlakova, I. M., Kubatko, O. V., Zyabyna, E. I. (2013). Ecological and economic potential of biogas technology in agriculture. Bulletin of SSU. Economy Series, 4, 19-25.

4. Shults, R. (2012). Production and use of biogas in Ukraine. Business center "Eurasia", 40.

5. Law of Ukraine "On Principles of Natural Gas Market" dated July 8, 2010 № 2467-VI (2010). Supreme Council of Ukraine, 48, 566.

6. Amona, T., Amona B. (2007). Biogas production from maize and dairy cattle manure. Agriculture, Ecosystems \& Environment, 118 (1-4), 173182. DOI: 10.1016/j.agee.2006.05.007.

7. Cuellar, A. D., Webber, M. E. (2008). Cow power: the energy and emissions benefits of converting manure to biogas. Environ. Res. Lett., 3 (034002), 8.

8. The Official Information Portal on Anaerobic Digestion (2014). Available at: www.biogas-info.co.uk.

9. Alvareza, R., Villca, S., Lidén, G. (2006). Biogas production from llama and cow manure at high altitude. Biomass and Bioenergy, 30 (1), 66-75. DOI: 10.1016/j.biombioe.2005.10.001.

10. Biogas upgrading and utilization: Energy from biological conversion of organics waste (2007). New York: IEA Bioenergy, 24, 24.

11. Holm-Nielsena, J. B., Al Seadi, T., Oleskowicz-Popiel P. (2009). The future of anaerobic digestion and biogas utilization. Bioresource Technology, 100 (22), 5478-5484. DOI: 10.1016/j.biortech.2008.12.046.

Рекомендовано до публікаиії докт. техн. наук Пляиук Л. Д. Дата надходження рукопису 21.07.2014.

Козій Іван Сергійович, кандидат технічних наук, старший викладач, кафедра прикладної екології, Сумський державний університет, вул. Римського-Корсакова, 2, м. Суми, Україна, 40007

E-mail: koziy.ivan@gmail.com

Мелейчук Станіслав Станіславович, кандидат технічних наук, доцент, кафедра технічної теплофізики, Сумський державний університет, вул. Римського-Корсакова, 2, м. Суми, Україна, 40007

E-mail: stanislav.meleychuk@gmail.com

Волохін Віталій Васильович, кандидат технічних наук, доцент, кафедра електроенергетики, Сумський державний університет, вул. Римського-Корсакова, 2, м. Суми, Україна, 40007

E-mail: vetvol-13@rambler.ru 